\title{
ACUTE KIDNEY INJURY FOLLOWING SURGERY FOR HIP FRACTURE
}

\author{
LESÃO RENAL AGUDA APÓS CIRURGIA \\ DE FRATURA DE QUADRIL
}

\author{
PHILIP MCKEAG ${ }^{1}$ (i), ANDREW SPENCE ${ }^{2}$ (1), BRIAN HANRATTY ${ }^{1}$ (1) \\ 1. Altnagelvin Hospital, Department of Trauma and Orthopaedic Surgery, Londonderry, United Kingdom. \\ 2. Royal Victoria Hospital, Department of Gastroenterology and Hepatology, Belfast, United Kingdom.
}

\section{ABSTRACT}

Objective: An observational study was carried out to determine the rate of acute kidney injury (AKI) following surgery for hip fracture at our institution and to look for factors associated with AKI. Methods: Preoperative creatinine values were compared to post-operative results for all patients who underwent surgery for hip fracture at our institution between $1^{\text {st }}$ January 2015 and $30^{\text {th }}$ September 2016. AKI was defined as an increase in postoperative creatinine, greater than or equal to 1.5 times the preoperative value within 7 days. Chi-squared test and Student's t-test were used to look for factors associated with AKI. Results: Out of 500 patients, 96 developed an AKI (19.2\%). Patients with chronic kidney disease (CKD) were more likely to develop AKI (30.8\%) that those without it $(17.2 \%, p=0.018)$. Similarly, patients with 2 or more comorbidities were more likely to develop AKI (22.0\%) than those without it $(12.4 \%, p=0.009)$. No statistically significant association was observed between type of surgery and AKI. Conclusion: A large proportion of patients following surgery for hip fracture developed AKI. Patients with CKD and the presence of 2 or more comorbidities had significantly higher rates of AKI. Level III evidence, Retrospective comparative study.

Keywords: Hip Fractures. Acute Kidney Injury. Hip. Hemiarthroplasty. Fracture Fixation. Arthroplasty, Replacement.

\section{RESUMO}

Objetivo: Estudo observacional realizado no Altnage/vin Hospital para determinar a taxa de lesão renal aguda ( $L R A)$ após a cirurgia de fratura de quadril e procurar fatores associados à LRA. Métodos: Os valores de creatinina pré-operatória foram comparados aos resultados pós-operatórios em todos os pacientes submetidos à cirurgia de fratura de quadril entre $1^{\circ}$ de janeiro de 2015 e 30 de setembro de 2016. A LRA foi definida como aumento da creatinina pós-operatória maior ou igual a 1,5 vezes ao valor pré-operatório dentro de 7 dias. Os testes qui-quadrado e t-Student foram usados para procurar fatores associados à LRA. Resultados: Dos 500 pacientes, 96 desenvolveram LRA (19,2\%). Pacientes com doença renal crônica (DRC) foram mais propensos a desenvolver $L R A$ $(30,8 \%)$ do que os pacientes sem a doença $(17,2 \%, p=0,018)$. Da mesma forma, pacientes com duas ou mais comorbidades foram mais propensos a desenvolver LRA (22,0\%) do que os pacientes sem comorbidades $(12,4 \%, p=0,009)$. Não houve associação estatisticamente significativa entre tipo de cirurgia e LRA. Conclusão: Após a cirurgia de fratura de quadril uma grande proporção de pacientes desenvolveu LRA. Pacientes com DRC e duas ou mais comorbidades tiveram taxas significativamente maiores de LRA. Nível de evidência III, Estudo comparativo retrospectivo.

Descritores: Fraturas do Quadril. Lesão Renal Aguda. Quadril. Hemiartroplastia. Fixação de Fratura. Artroplastia de Substituição.

Citation: McKeag P, Spence A, Hanratty B. Acute kidney injury following surgery for hip fracture. Acta Ortop Bras. [online]. 2020;24(1):128-30. Available from URL: http://www.scielo.br/aob.

\section{INTRODUCTION}

Hip fracture is a rising epidemic associated with prolonged stay in hospital and reduction in quality of life. ${ }^{1}$ Acute kidney injury (AKI) following surgery for hip fracture is common. ${ }^{2}$ Long- and short-term mortality rates are higher for patients who develop AKI following surgery for hip fracture compared to those who do not. $^{3,4}$ This group of patients is aging with more comorbidities. ${ }^{5}$ Recent studies have shown that increasing age and number of comorbidities are associated with significantly more patients developing AKI following surgery for hip fracture. ${ }^{6}$ Observational studies have shown that up to $21 \%$ of patients following surgery for hip fracture can develop AKI; however, results vary among studies. ${ }^{6,7}$ The purpose of this study was to determine how many patients developed AKI following hip fracture in our institution and if previously suggested risk factors for postoperative AKI are true for this patient sample. 


\section{METHODS}

All patients aged over 65 years who underwent surgery for hip fracture at Altnagelvin Area Hospital between 01/01/2015 and 09/21/2016 were identified using our hip fracture database.

Baseline serum creatinine concentration (day of hospital admission) and postoperative serum creatinine concentration (day 1 and 4) were recorded at the Northern Ireland Electronic Care Record. Recorded information also included age, sex, type of fracture and surgery, date and duration of surgery, length of stay in hospital and medical comorbidities.

AKI was defined as an increase in postoperative serum creatinine concentration greater than or equal to 1.5 times the baseline value within 7 days.

\section{Statistics}

Results are presented as mean and standard deviation (SD) for continuous variables. Binary and categorical variables are summarized by frequency. Chi-squared test and Student's t-test were used to investigate risk factors associated with post-surgical AKI (increasing age, male sex, chronic kidney disease-CKD and 2 or more comorbidities). All analyses were performed with IBM SPSS Statistics version 20 (IBM Corporation, New York, US).

\section{RESULTS}

Baseline patient characteristics are summarized in Table 1. The mean age was 81.4 years and most patients were women. Frequent comorbidity included ischaemic heart disease (13\%), chronic obstructive pulmonary disease $(11.2 \%)$ and $14.2 \%$ of patients had a history of diabetes mellitus. The most common type of operation performed was hip hemiarthroplasty (46.8\%), followed by dynamic hip screw insertion (29.8\%) and long intramedullary nail insertion (16.2\%). The least common operation performed was total hip replacement (7.2\% of patients). The mean preoperative serum creatinine was 90 micromoles per liter.

Out of 500 patients aged over 65 years who underwent surgery for hip fracture, 96 developed AKI (19.2\%).

Table 1. Baseline patient characteristics and type of surgery.

\begin{tabular}{c|c}
\hline & $\begin{array}{c}\text { All Patients } \\
\mathbf{N}=500\end{array}$ \\
\hline Mean age, years (SD) & $81.4(8.6)$ \\
\hline Sex, $\mathbf{n}(\%)$ & $133(26.6)$ \\
\hline Male & $367(73.4)$ \\
\hline Female & $65(13.0)$ \\
\hline Past Medical History, $\mathbf{n}(\%)$ & $56(11.2)$ \\
\hline Ischaemic heart disease & $49(9.8)$ \\
\hline Chronic obstructive pulmonary disease & $71(14.2)$ \\
\hline Cerebrovascular accident & $31(6.2)$ \\
\hline Diabetes mellitus & $149(29.8)$ \\
\hline Myocardial infarction & $234(46.8)$ \\
\hline Type of Surgery, $\mathbf{n}$ (\%) & $81(16.2)$ \\
\hline Dynamic hip screw & $36(7.2)$ \\
\hline Hip hemiarthroplasty & $90(50.0)$ \\
\hline Long intramedullary nail & \\
\hline Total hip replacement &
\end{tabular}

Table 2 shows the risk factors known to be associated with AKI following surgery for hip fracture. Patients with chronic kidney disease and the presence of 2 or more comorbidities had significantly higher rates of $\mathrm{AKI}$ ( $\mathrm{p}$-value $=0.018$ and 0.009 respectively).
A significant difference was identified between mean preoperative serum creatinine concentration and development of $A K I(p=<0.001)$. No significant difference was found regarding sex ( $p=0.200)$, mean age or type of surgery performed $(p=0.282)$ and development of $A K I(p=0.459)$.

\begin{tabular}{|c|c|c|c|}
\hline & $\begin{array}{l}\text { Patients } \\
\text { with AKI }\end{array}$ & $\begin{array}{c}\text { Patients } \\
\text { without AKI }\end{array}$ & $p$ value \\
\hline Mean age, years (SD) & $82.5(9.1)$ & $81.1(8.4)$ & $\begin{array}{c}0.459 \\
\text { Student's t-test }\end{array}$ \\
\hline \multicolumn{4}{|l|}{ Sex, $n(\%)$} \\
\hline Male & $30(6.0)$ & $103(20.6)$ & \multirow{2}{*}{$\begin{array}{c}0.200 \\
\text { Chi-squared test }\end{array}$} \\
\hline Female & $66(13.2)$ & $301(60.2)$ & \\
\hline \multicolumn{4}{|l|}{ Type of Surgery, $\mathbf{n}(\%)$} \\
\hline Dynamic hip screw & $25(5.0)$ & $124(24.8)$ & \multirow{3}{*}{$\begin{array}{c}0.282 \\
\text { Chi-squared test }\end{array}$} \\
\hline Hip hemiarthroplasty & $44(8.8)$ & $190(38.0)$ & \\
\hline Long intramedullary nail & $22(4.4)$ & $59(11.8)$ & \\
\hline Total hip replacement & $6(1.2)$ & $30(6.0)$ & \\
\hline \multicolumn{4}{|l|}{ Comorbidities, n (\%)* } \\
\hline$\geq 2$ comorbidities & $78(15.6)$ & $277(55.4)$ & \multirow{2}{*}{$\begin{array}{c}0.009 \\
\text { Chi-squared test }\end{array}$} \\
\hline$<2$ comorbidities & $18(3.6)$ & $127(25.4)$ & \\
\hline $\begin{array}{l}\text { Chronic kidney } \\
\text { disease, n (\%) }\end{array}$ & $20(4.0)$ & $45(9.0)$ & \multirow{2}{*}{$\begin{array}{c}0.018 \\
\text { Chi-squared test }\end{array}$} \\
\hline $\begin{array}{l}\text { No chronic kidney } \\
\text { disease, } n(\%)\end{array}$ & $75(15.0)$ & $360(72.0)$ & \\
\hline $\begin{array}{c}\text { Mean preop creatinine } \\
\text { concentration, } \\
\text { micromoles/l (SD) }\end{array}$ & $109.0(80.0)$ & $85.0(39.0)$ & $\begin{array}{l}\quad<0.001 \\
\text { Student's t-test }\end{array}$ \\
\hline
\end{tabular}
${ }^{\star}$ Cerebrovascular accident, transient ischaemic attack, cardiovascular disease, chronic obstructive pulmonary disease.

\section{DISCUSSION}

Recent studies have shown that between $12.7 \%$ and $24.0 \%$ of patients develop AKI following surgery for hip fracture..$^{2-4,6,7}$ In this study, $19.2 \%$ of patients developed AKI within 7 days of surgery for hip fracture. This is comparable to the findings from other recent studies. Variability exists in relation to how AKI is defined, and this may contribute to the differences presented in numbers of patients developing AKI.

In one of the largest studies investigating AKI following surgery for hip fracture, $12.7 \%$ of 13,529 patients from hospitals in Denmark developed $\mathrm{AKI} .{ }^{8}$ Baseline serum creatinine was estimated using an electronic database of blood results. ${ }^{8}$ The highest serum creatinine value in the first 5 postoperative days was compared to baseline. ${ }^{8}$ AKI was defined according to the criteria in The Kidney Disease Improving Global Outcome (KIDGO) classification. ${ }^{9}$

A similar study included 2,959 patients from UK hospitals. ${ }^{10}$ Baseline serum creatinine was estimated using the Modification of Diet and Renal Disease (MDRD) equation. ${ }^{10}$ Then this result was compared to the highest postoperative value for the length of hospital stay. ${ }^{10}$ AKI was defined again according to the KIDGO classification. A total of $24 \%$ of patients developed a post-surgical AKI. ${ }^{10}$

One modifiable factor that may affect the development of postoperative $\mathrm{AKI}$ is the antibiotic choice for surgical prophylaxis. In this study, all patients received flucloxacillin and gentamicin. Higher rates of $\mathrm{AKI}$ among patients receiving flucloxacillin and gentamicin have been seen compared to cephalosporins for elective hip and knee surgery. ${ }^{11}$ 
Intraoperative measures also play an important role in preventing postoperative AKI. Hypovolaemia due to intraoperative blood loss will lead to reduced renal perfusion. ${ }^{12,13}$ Even short periods of low mean arterial pressure are poorly tolerated and associated with increased risk of postoperative AKI.12,13 This fact highlights the importance of accurate measurement of intraoperative blood loss, recording of blood pressure while the patient is anesthetize and careful assessment of fluid balance in the perioperative period. ${ }^{12,13}$ Another important modifiable risk factor for the development of postoperative $\mathrm{AKI}$ is the administration of nephrotoxic or potentially nephrotoxic medications. ${ }^{14}$ Drugs associated with an increased risk of AKI in general are non-steroidal anti-inflammatory drugs, angiotensin converting enzyme inhibitors and angiotensin receptor blockers, and mineralocorticoid receptor antagonists. ${ }^{14,15}$ If possible, these drugs should be discontinued preoperatively and held in the perioperative period. ${ }^{14,15}$

In this study, the proportion of patients developing AKI was significantly higher in those patients with a past history of CKD or the presence of 2 or more comorbidities when compared to those without. This is in keeping with findings from other studies. ${ }^{2-5,8}$ Porter et al., ${ }^{10}$ in a recent observational study, found a significant number of patients who developed AKI following surgery for hip fracture with a history of
CKD or the presence of 2 or more comorbidities. Additional factors known to increase the risk of AKI following surgery for fractured neck of femur include increased age and being men. ${ }^{8}$ In this study, the proportion of patients developing AKI was not significantly different for patients with these risk factors compared to those without. The reason for this is not clear, but one possible explanation is that the study size was insufficient to present a significant difference.

This study has a number of limitations. Firstly, data collection was retrospective, introducing an element of recall bias. Secondly, no information was recorded about patient medication being potentially nephrotoxic, which could have affected the results. Finally, although the proportion of patients developing $\mathrm{AKI}$ in this study is in keeping with other recent studies, the sample size is still relatively small. Further studies are required to analyze the type of operation performed for hip fracture and the subsequent development of AKI.

\section{CONCLUSION}

In this single-center observational study involving 500 patients, $19.2 \%$ developed acute kidney injury within 7 days following surgery for hip fracture. Patients with a medical history of CKD and 2 or more comorbidities were more likely to develop AKI than those without it.

AUTHORS' CONTRIBUTIONS: Each author contributed individually and significantly to the development of this article: PM: concept/design, data analysis/ interpretation, drafting of the article; AS: data analysis/interpretation, critical revision of the article; $\mathrm{BH}$ : concept/design, data analysis/interpretation, critical revision of the article.

\section{REFERENCES}

1. Scottish Intercollegiate Guidelines Network. Management of hip fracture in older people: a national clinical guideline. Edinburgh; 2009.

2. Bennet SJ, Berry OM, Goddard J, Keating JF. Acute renal dysfunction following hip fracture. Injury. 2010;41(4):335-8

3. Khan MA, Hossain FS, Ahmed I, Muthukumar N, Mohsen A. Predictors of early mortality after hip fracture surgery. Int Orthop. 2013;37(11):2119-24.

4. Hong SE, Kim TY, Yoo JH, Kim JK, Kim SG, Kim HJ, et al. Acute kidney injury can predict in-hospital and long-term mortality in elderly patients undergoing hip fracture surgery. PloS One. 2017;12(4):e0176259.

5. Baker PN, Salar O, Ollivere BJ, Forward DP, Weerasuriya N, Moppett I K, et al. Evolution of the hip fracture population: time to consider the future? A retrospective observational analysis. BMJ Open. 2014;4(4):e004405.

6. Ulucay C, Eren Z, Kaspar EC, Ozler T, Yuksel K, Kantarci G, et al. Risk factors for acute kidney injury after hip fracture surgery in the elderly individuals. Geriatr Orthop Surg Rehabil. 2012;3(4):150-6.

7. Azevedo VL, Silveira MA, Santos JN, Braz JR, Braz LG, Módolo NS. Postoperative renal function evaluation, through RIFLE criteria, of elderly patients who underwent femur fracture surgery under spinal anesthesia. Ren Fail. 2008;30(5):485-90.
8. Pedersen AB, Christiansen CF, Gammelager H, Kahlert J, Sørensen HT. Risk of acute renal failure and mortality after surgery for a fracture of the hip: a population-based cohort study. Bone Joint J. 2016;98-B(8):1112-8.

9. International Society of Nephrology. KDIGO clinical practice guideline for acute kidney injury. Kidney Int Suppl. 2012;2(1).

10. Porter CJ, Moppett IK, Juurlink I, Nightingale J, Moran CG, Devonald MA. Acute and chronic kidney disease in elderly patients with hip fracture: prevalence, risk factors and outcome with development and validation of a risk prediction model for acute kidney injury. BMC Nephrol. 2017;18(1):20.

11. Bailey O, Torkington MS, Anthony I, Wells J, Blyth M, Jones B. Antibiotic-related acute kidney injury in patients undergoing elective joint replacement. Bone Joint J. 2014;96-B(3):395-8.

12. Goren $\mathrm{O}$, Matot I. Perioperative acute kidney injury. $\mathrm{Br} \mathrm{J}$ Anaesth. 2015;115 Suppl 2:ii3-14.

13. Webb ST, Allen JSD. Perioperative renal protection. CEACCP. 2008;8(5):176-80

14. Coca SG, Yusuf B, Shlipak MG, Garg AX, Parikh CR. Long-term risk of mortality and other adverse outcomes after acute kidney injury: a systematic review and meta-analysis. Am J Kidney Dis. 2009;53(6):961-73.

15. Meersch M, Schmidt C, Zarbock A. Perioperative acute kidney injury: an under-recognized problem. Anesth Analg. 2017;125(4):1223-32. 